\title{
Portrait of René Girard as a Post-Hegelian: Masters, Slaves, and Monstrous Doubles
}

\author{
Andreas WILMES \\ Centre de Recherche sur les Liens Sociaux (CERLIS), \\ Université Paris-Descartes, France
}

\begin{abstract}
This paper will analyze the evolution and the key aspects of René Girard's critique of the Hegelian "struggle for recognition" and the master-slave dialectic. Through a discussion of Girard's views on Identity, Difference, Violence, Desire and Negativity, the study will aim to highlight the philosophical uniqueness of the mimetic theory in respect to French Hegelianism and postHegelianism.
\end{abstract}

\section{Keywords}

René Girard; Georg Wilhelm Friedrich Hegel; Alexandre Kojève; Georges Bataille; Modern French Philosophy; Dialectic; Mimetic theory; Conflict; Violence; War.

"The danger in Hegel's thought comes paradoxically from the fact that it does not begin with a sufficiently radical conception of violence."

René Girard

\section{Introduction}

In 1978, Raymund Schwager noticed "surprising analogies between Hegel's constantly recurring theme of dialectical self-alienation and Girard's analyses of self-projection, of the double, and of mimetic rivalry." Schwager wrote that a comparative study of The Phenomenology of Spirit and Violence and the Sacred would benefit future research. Studies on the philosophical differences and affinities between Girard and Hegel are, unfortunately, still scarce. This is not the sole regret of contemporary research on Hegelianism; it is also unfortunately so for the philosophical understanding of René Girard's theories as well. On one hand, Hegelians have largely ignored an author whose form of criticism can neither be reduced to the classic $19^{\text {th }}$ century rejectionists of German Idealism (Kierkegaard, Marx and Nietzsche), nor to the general framework of modern French anti-Hegelianism (Deleuze, Foucault, Bataille, Lacan). However, on the other hand, the difference between the mimetic

1 Raymund Schwager. Must There Be Scapegoats? Violence and Redemption in the Bible (New York: Gracewing, 2000), 35.

This is an Open Access article distributed in accordance with the Creative Commons Attribution Non Commercial (CC-BY-NC-ND 4.0) license, which permits others to copy or share the article, provided original work is properly cited and that this is not done for commercial purposes. Users may not remix, transform, or build upon the material and may not distribute the modified material (http:/ / creativecommons.org/ licenses/by-nc/4.0/) 
theory and Hegelianism appears as an ongoing concern in Girard's writings. In his first book, Deceit, Desire and the Novel (1961), he aimed to distinguish the figures of triangular desire from those of Hegel's Phenomenology of Spirit (DDN, 17;110-112). In some of his later works, several concise remarks reiterate his opposition to the German philosopher. And further, in his final book, Battling to the End, Girard admits that while he wrote Deceit, Desire and the Novel, he "felt an affinity with Hegel's philosophy" (BE, p. 30; $A C$, p. 72) and that during the early period of his career he "did not dare" to demonstrate what he refers to as the "prosaic" (BE, p. 31; $A C$, p. 73) difference distinguishing his own conception of desire from the famous struggle for recognition introduced in The Phenomenology of Spirit. Suddenly, a philosopher, scarcely mentioned and discussed previously by the French anthropologist, becomes a pivotal character in his final, and perhaps most ambitious, essay. For Girard's opposition to Hegel will not only entail a debate on the nature of human conflicts and desires, it entails a wider discussion on the characteristics of war, religion, and history.

It has been recently observed that while Girard engaged in critical debates with many major philosophers (Friedrich Nietzsche, Martin Heidegger, Gilles Deleuze to name just a few), his struggle with Hegelianism seems to have been the most difficult ${ }^{2}$. This is certainly true, but this peculiar difficulty also requires some explanations.

Broadly speaking, Hegel and Girard are comparable in many respects. Both aim to bypass the traditional subject-object dichotomy; introduce an intersubjective (Girard would say "interdividual") conception of desire and violence; deliver a sharp criticism of modern individualism and romanticism; establish a strong link between science and religion; as well as base the structure and logic of their philosophy of history on the Christian revelation. While the German philosopher and the French anthropologist do not tackle the aforementioned issues and topics the same way, their intellectual projects nonetheless share some common and important themes.

Yet, in an unpublished manuscript from 1986, "L'amitié qui se transforme en haine" ("Friendship turning into hatred", an interesting title for our subject matter as we shall see further on), Girard states that some misinterpretations have been detrimental to the correct understanding of the theory of mimetic desire. Among them, he mentions the tendency to "confuse" mimetic desire with "Hegel's desire for recognition" 3 ". This confusion was probably not contested from the start, for as noted by Benoit Chantre, the philosopher Lucien Goldmann played an important part in the French intellectual reception of Deceit, Desire and the Novelt. In Goldmann's review ${ }^{5}$, the work of Girard (who was already influenced by his readings of Alexandre Kojève) was compared to Karl Marx and György Lukács and, thus, placed under the sign of Hegel's legacy. But even a few decades later, the supposedly Hegelian aspects of Girard's anthropology would frequently be emphasized. In 1975, Philippe Lacoue-Labarthe raises "the question ... of Girard's, seemingly paradoxical, refusal to deal directly with Hegel. ${ }^{\text {" }}$ From his standpoint, the anthropologist "fails to come

\footnotetext{
2 Paul Dubouchet, De Georg Wilhelm Friedrich Hegel à René Girard. Violence du droit, religion et science (Paris : L'Harmattan, 2015), 8.

3 "Certains facteurs intellectuels desservent encore le désir mimétique sur le plan de la pensée (...). On peut le confondre, par exemple, avec le désir de reconnaissance de Hegel." René Girard. "L'amitié qui se transforme en haine", in Cabier René Girard, ed. Mark R. Anspach, (Paris: Editions de L'Herne, 2008), 198-202.

${ }^{4}$ Benoit Chantre, "René Girard in France", Contagion 23 (2016) :16-19.

${ }^{5}$ Lucien Goldmann, “ Marx, Lukács, Girard et la sociologie du roman”, Méditations, revue des expressions contemporaines 2 (1961): 143-153.

6 Philippe Lacoue-Labarthe, Typography. Mimesis, Philosophy, Politics (Palo Alto: Stanford University Press, 1998), 105.
} 
sufficiently to grips with" "he German philosopher. In Things Hidden Since the Foundation of the World, Girard replies that Lacoue-Labarthe's references to Hegelianism are mainly due to a serious misunderstanding of the conception of desire introduced by the mimetic theory ${ }^{8}$. Nonetheless, a few years later Mikkel Borch-Jacobsen contends that we can trace back the philosophical foundations of Girard's critique of psychoanalysis to Kojève's lectures on The Phenomenology of Spirit where the idea of "Desire directed toward another Desire" $(\operatorname{IRH}, 5)$ appears as a key element to understanding the Hegelian struggle for recognition". Albeit that they mention with a greater insistence that Girard's hypothesis of the scapegoat mechanism sets him apart from other philosophers, Eugene Webb ${ }^{10}$, George Erving ${ }^{11}$ and Guy Vanhesswijck ${ }^{12}$ also agree that his conception of mimetic desire is of Hegelian inspiration. Finally, Jean-Marie Domenach labeled Girard as the "Hegel of Christianity 13". Behind this expression (which some have considered misleading ${ }^{14}$ ), Domenach is actually criticizing the systematization of knowledge vindicated by the mimetic theory. According to him, Girard, in the same fashion as Hegel, tends to impose a definitive meaning on the history of mankind. Where Hegel once told us of the "end of history", Girard now leaves us with no choice in the face of the Apocalypse and the inevitable necessity of Christian conversion.

It is difficult to understand the stakes of the Hegel-Girard issue, especially when the intellectual context of French modern philosophy is ignored. As Chantre recently observed:

We must keep in mind that, although he [Girard] lived in the US and became a citizen in 1956, he always kept his sights on his native land. He watched the transformations of French thought from the other side of the ocean; he forged his own writing strategies in response to French thought; and it was within the context of French debates that he chose to formulate, through the conjoined hypotheses concerning mimetic desire, the scapegoat, and Judeo-Christian writing, the founding event of his return to Christianity in $1959 .{ }^{15}$

Now, Girard belonged to a period in France where critical debates on Hegelianism were an increasing and major intellectual concern. Just as was Girard during the writing of Deceit, Desire and the Novel, many notorious French philosophers and intellectuals (i.e. Georges Bataille, Raymond Aron, Roger Caillois, Maurice Merleau-Ponty, Jacques Lacan, Eric Weil) were influenced by Alexandre Kojève's interpretation of The Phenomenology of Spirit, which

\footnotetext{
7 Ibid., 118.

8 René Girard, Des choses cachées depuis la fondation du monde (Paris : LGF, 1983), 27-29.

${ }^{9}$ Mikkel Borch-Jacobsen, Lacan, le maître absolu (Paris: Flammarion, 1995), 305-306. Borch-Jacobsen mentions Girard's "not altogether convincing declaration of anti-Hegelianism". According to him, Girard's anthropology is mainly an "extremely brilliant" "accentuation ... of the specifically Kojevian theme of the 'desire of the desire of the other'." See also Mikkel Borch-Jacobsen, Folies à plusieurs. De l'bystérie à la dépression (Paris: Seuil, 2002), 305.

${ }_{10}$ Eugene Webb, The Self Between. From Freud to the New Social Psychology of France (Seattle: University of Washington Press, 1992), 116.

11 George Erving, "René Girard and the Legacy of Alexandre Kojève", Contagion 10 (2003): 111-125.

12 Guy Vanheeswijck, "The Place of René Girard in Contemporary Philosophy", Contagion 10 (2003): 98.

13 Jean-Marie Domenach, Enquête sur les idées contemporaines (Paris : Seuil, 1981), 107.

14 Paul Dubouchet, De Georg Wilhelm Friedrich Hegel à René Girard. Violence du droit, religion et science, 113114. Dubouchet contends that "Hegel of Christianity" is nearly a pleonasm. According to him, even if Girard would certainly have refused this labelling, "Hegel of Catholicism" (as opposed to the German philosopher's Protestantism) would have been a more relevant expression.

15 Benoît Chantre, "René Girard in France", 13.
} 
was introduced in his famous lectures at the École Pratique des Hautes Etudes from 1933 to 1939. Other famous philosophers like Gilles Deleuze, Jacques Derrida, and Michel Foucault were the students of Jean Hyppolite who, in the 1940's, wrote the first authoritative and comprehensive French translation of Hegel's Phenomenology of Spirit. More importantly, Girard, like many of his contemporaries, was involved in the French antiHegelian turn of the 1960's. As stated by Descombes:

In 1945, then, all that was modern sprang from Hegel, and the only way to reconcile the contradictory demands of modernity was to advance an interpretation of Hegel. In 1968, all that was modern (...) was hostile to Hegel. The difference separating the two generations lies in the inversion of the sign that marked the relationship to Hegel: everywhere a minus was substituted for the plus. The reference point itself remained the same, but in the one case the concern was with drawing towards it (returning, like the prodigal son, to the Hegelian earth), whereas in the other it was with drawing away (putting an end to the tyranny of Hegelianism). ${ }^{16}$

This philosophical Zeitgeist is perhaps best captured by Michel Foucault's famous statement during his inaugural lecture in 1970 at the Collège de France: "our entire epoch, whether in logic or epistemology, whether in Marx or Nietzsche, is trying to escape from Hegel. ${ }^{17}$ " Girard, just as many others, would face the issue of bypassing Hegelianism in a relevant and coherent way. For in this period, the strengths granted to Hegelian dialectic were virtually prodigious in scope. Not only did the philosophical system of the German Idealist defy the most current conceptual oppositions; it also appeared able to bypass or absorb antagonistic standpoints which, at first glance, seemed to undermine it. In their confrontation with Hegel, some authors, such as Georges Bataille, went so far as to defy the very limits of human language. In brief, specifying Girard's position vis-à-vis Hegel means specifying his place within the context of French modern philosophy.

Guy Vanhesswijck was right when he wrote that Girard belongs to the intellectual "generation which, on the one hand, embroiders on the theme of desire, borrowed from Kojève's interpretation of Hegel, but, on the other, in its search for answers, precisely wishes to get rid of Hegel. ${ }^{18}$ " Yet, we will see that Vanhesswijck overlooked the peculiarity of Girard's standpoint in the French intellectual context. Rather than defining Girard as a "typical postmodern author ${ }^{19}$ " influenced by the "seminal" and post-Hegelian "theme of " difference"20", I shall contend here that Girard was like no other anti-Hegelian. As a matter of fact, he is perhaps the only one who aimed to surpass Hegel by radicalizing the logic of his dialectic from within instead of criticizing his system from the ill-founded notion of "difference". By privileging a renewed way of thinking about imitation and identity instead of the common postmodern theme of "difference", Girard's works introduced a major change which deserves more philosophical consideration. To vindicate this standpoint in a more clear and comprehensive way, first, we will briefly introduce Hegel's master and slave dialectic and its interpretations by Alexandre Kojève and Georges Bataille. Then, we will discuss Girard's critique of the Hegelian struggle for recognition and, eventually, highlight

\footnotetext{
16 Vincent Descombes, Modern French Philosophy (New York: Cambridge University Press, 1980), 12.

17 Michel Foucault, "The Order of Discourse" (Inaugural Lecture at the Collège de France, 2 December 1970)", in Untying the Text: a Post-Structuralist Reader, ed. Robert Young (Boston: Routledge, 1981), 74.

${ }^{18}$ Guy Vanheeswijck, “The Place of René Girard in Contemporary Philosophy”, 96.

${ }^{19}$ Ibid., 99.

${ }^{20}$ Ibid., 97.
} 
its uniqueness in the context of French modern philosophy. It shall be noted that my intent is not to offer a comprehensive comparative study on Girard and Hegel. My remarks will be limited to the unique nature of Girard's standpoints with respect to more common Hegelian and anti-Hegelian trends. Notably, the critique of Hegel's views on international wars and its confrontation with the work of Carl von Clausewitz (which constitutes an important part of Battling to the End) will only be mentioned briefly. The way in which Girard revisited the themes of desire, conflict, violence, identity and difference will remain at the center of the discussion.

\section{Hegel's master and slave dialectic and his reception by French modern philosophy}

It is always an arduous task to summarize Hegel's dense and rigorous reasoning in a few paragraphs. However, the intent here is not to provide the reader with an in-depth study of The Phenomenology of Spirit. Rather I would like to give a jargon-free account of the struggle for recognition and the master and slave dialectic to stress the most salient aspects that will later be discussed as understood by Kojève, Bataille, and Girard. I will omit many philosophical debates on Hegel's text, but this will not affect my reading and vindication of Girard's critique, for his angle of approach consists in addressing a peculiar conception of violence which is not reducible to Hegelian and post-Hegelian schools of thought.

\section{A. The struggle for recognition and the conquest of Self-Consciousness}

Section B of Hegel's Phenomenology of Spirit, titled "Self-Consciousness", can first be read as a critique and homage to Cartesian philosophy. René Descartes was the first philosopher who, instead of trying to seek the truth outside of himself, explained that the most logical starting point is the certainty we have about ourselves. Hegel certainly considers that Descartes's cogito was a major step in the history of philosophy. However, he also contends that the Cartesian self-certainty is an abstract and formal one. To remain intact in its selfcertainty, consciousness needs permanent imports from the external world: it needs to be nourished or sustained by some content, otherwise, consciousness would sink into the vagueness and inconsistency of dreams. Hegel, as Girard, considers that human consciousness suffers from a constitutive emptiness. This void aims to be filled through the act of consumption. Consciousness, seemingly purports to absorb and assimilate what is non-identical to it. It is at this very moment that desire, in Hegel's philosophy, comes into play. In The Phenomenology of Spirit, desire can be defined as an attempt of destruction and assimilation. On the one hand, it clearly has a negative value (Kojève would even say that desire is an act of negation in itself). However, on the other hand, some scholars stress the positive side of Hegel's view on desire. For desire, in the end, also shows that nature can leave room for human interests.

In the act of consumption, desire appears as a loose basis in respect to the self-certainty of consciousness. Through desire, the agent manifests his dependency regarding the external world and, more generally, life, in the biological sense. While he constantly negates objects through consumption, these constantly reappear, resulting in a never-ending process. The next logical step, in this understanding of desire, is to seek an object that can negate itself, that is, a consciousness presenting itself as an object of never-ending consumption for another consciousness. This is Hegel's starting point for his dialectic of love, that is, in its most sensible and sexual dimension (Hegel employs the German term "Gattung"; PHG, 143). Through love, consciousness begins to reach the universality of its natural kind. Two agents are recognizing each other in their flesh. Yet, this first form of recognition, in the realm of sensibility, turns out to be a logical dead end. For in the case of 
love, the two agents show each other to be objects of consumption. Thereby, they are absolutely interchangeable and nothing can prove that the consciousness's pretense of selfcertainty is really grounded.

The logical transition leading to the well-known episode of "Lordship and Bondage" is, in brief, the following: to be grounded in self-certainty, "each must demonstrate to bimself that he is more than just an organism by being recognized as such by the other agent ${ }^{21}$ ". In other words, the agents cannot accept to be only recognized in their flesh, but they aim to be recognized as a being whose legitimacy goes beyond nature, again, in the biological sense. They need to be recognized as more than a simple object by another consciousness. From this mutual determination of each one to prove its "independence over life itself22", a growing state of violent reciprocity will emerge. This is, as Jean-François Marquet recently observed, a spectacular logical transition from love to conflict ${ }^{23}$. No one can gain recognition, contends Hegel, if the struggle ends in violent death. As we shall see, the exclusion of death in the conflict-scenario will become the main target of both Bataille's and Girard's criticism. However, it is worth mentioning that Hegel's remarks on death rest on logical considerations. For recognition needs to be ascertained in an objective way and cannot be founded on the simple pretense of one single subject, otherwise, the claims for self-certainty would collapse just as in the previous steps. If not grounded in the eye of another consciousness, the negation of life is purely formal and inconsistent. Therefore, Hegel calls death an "abstract negativity" ("abstrakte Negation"; PHG, 150), that is, it is negativity detrimental to the logic and progress of self-certainty claims.

Thus, during conflict someone must back away due to the fear of his own death: this will be the slave working on the objects of the natural world for his master's enjoymentwho, of course, did not hesitate to put his life at substantial risk. At first glance, it seems that only the latter has gained authentic recognition. But Hegel will show us the other side of this relation of domination and servitude, for during the struggle, the slave experienced something far more profound and important than his master did (PHG, 153): he shuddered at the possibility of his own death and, thereby, discovered the "full contingency of everything 24 ". If this only concerned the slave's personal experience, this negativity would be considered as an abstract one, but it is not, since the slave works on objects of the natural world that are to be consumed by his master (PHG, 153-155). Thereby, the slave learns to postpone his desires and to delay his gratification. Eventually, he can reflect on the objects of the natural world as exchange values shaped by his labor and addressed to his master's needs. In other words, the slave bypassed the logical dead end of "abstract negativity". The negativity of the near-death experience becomes externalized in the act of labor. The opposition of life to itself is maintained and surpassed (Aufgehoben in Hegelian terms) in a new configuration. From a logical perspective, it is the slave who attained a new step regarding the objectivation of his self-certainty claims, not the master whose position finally appears as purely contingent. Thus, according to Hegel, the long ethical path of reciprocal recognition has begun.

\footnotetext{
${ }^{21}$ Terry Pinkard, Hegel's Phenomenology. The Sociality of Reason (Cambridge: Cambridge University Press, 1996), 57.

22 Ibid., 58.

23 Jean-François Marquet, Leçons sur la Phénoménologie de l'esprit de Hegel (Paris: Ellipses, 2009), 97. Interestingly, Marquet introduces an anthropological analogy with Marcel Mauss's studies on the potlach. This rivalry of lavishing gifts and wasting property was, as we know, a recurrent topic in Girard works.

${ }^{24}$ Terry Pinkard, Hegel's Phenomenology. The Sociality of Reason, 61.
} 


\section{B. Kojève's existential and anthropological reading of Hegel's Phenomenology}

Although it was very influential, Kojève's interpretation of The Phenomenology of Spirit includes some salient and peculiar aspects which are, generally speaking, no longer accepted by contemporary Hegelian commentators. One of the most conspicuous changes introduced by Kojève is perhaps the replacement of Hegel's monism by a dualist ontology. As we just saw, Hegel's dialectic rests on the logic of the self-reflection of life. In other words, life is first given in its unreflected immediacy, then it divides itself during the episode of the struggle and finally becomes mediated and reflected in the slave's experience of death and labor. Kojève, on the contrary, operates a strong division between life, in its naturalness and immediacy, and the human reality. This is what we may call, after Descombes, the "humanization of nothingness 25 ". Negation (or "negating-negativity"), as Kojève clearly states in his Introduction to the reading of Hegel, is primarily an action that sets apart man from animal. His reading of The Phenomenology of Spirit is undoubtedly focused on the selfproductive process of human reality:

This I will not, like the animal "I," be "identity" or equality to itself, but "negating-negativity." In other words, the very being of this I will be becoming and the universal form of this being will not be space, but time. Therefore, its continuation in existence will signify for this I: "not to be what it is (as static and given being, as natural being, as 'innate character') and to be (that is, to become) what it is not." Thus, this I will be its own product: it will be (in the future) what it has become by negation (in the present) of what it was (in the past), this negation being accomplished with a view to what it will become. In its very being this I is intentional becoming, deliberate evolution, conscious and voluntary progress; it is the act of transcending the given that is given to it and that it itself is. This I is a (human) individual, free (with respect to the given real) and historical (in relation to itself). And it is this $\mathrm{I}$, and only this $\mathrm{I}$, that reveals itself to itself and to others as Self- Consciousness. (IRH, 5)

As a matter of fact, Kojève combined Hegel's reflections on Self-Consciousness with other philosophical influences. First, following Feuerbach and Marx, Kojève rephrases Hegel's speculative philosophy in a "humanistic" and "anthropological26" framework. As well, it is highly plausible that Kojève interpreted the negativity experienced and externalized by the slave in the light of the Heideggerian notion of "Being-toward-death". This philosophical project is not without challenge. On the one hand, the notion of negation or negativity outlined by The Phenomenology of Spirit becomes radicalized and scholars are entitled to wonder if such a shift is still compatible with the classic conception of Hegelian reasoning. A radical negativity cannot be Aufgehoben, and would, so to speak, get stuck right in the middle of the dialectical process. On the other hand, Heidegger, especially in his "Letter on Humanism", made it clear that his views on the Dasein preclude the idea of "a power of nihilation that human being could purely and simply appropriate ${ }^{27}$ ".

These philosophical amendments, however, encouraged a distinctive conception of human desire which, as we shall see, bears some, perhaps superficial, resemblances to Girard's mimetic theory. In Kojève's reading of Hegel, the struggle for recognition becomes the theoretical matrix for the understanding of human history which is no more than a

\footnotetext{
25 Vincent Descombes, Modern French Philosophy, 9.

26 George Erving, "René Girard and the Legacy of Alexandre Kojève", 113.

27 Mikkel Borch-Jacobsen, Lacan, le maître absolu, 32.
} 
history of desire. Far from being a one-off episode of The Phenomenology of Spirit, the struggle to death leading to domination and servitude becomes the cornerstone for understanding the progressive self-constitution of a free and purely human reality. It can be understood from this perspective that "the historical 'dialectic' is the 'dialectic' of Master and Slave" $(I R H, 9)$. For Kojève, the negative force of desire first refers to the constitutive emptiness of human consciousness. By simply annihilating and absorbing objects of the natural world, man cannot ascertain his essential difference with respect to the immediacy of biological life. He needs the "negating-negativity" of his desire to be recognized by another consciousness. Each consciousness must see the negativity of its desire in the Other, as in a mirror. Therefore, through this shared aim, each agent will indeed desire the desire of the other. Each one desires to be desired in its ability to transcend the given and immediate natural world. Simply put, human desire is fundamentally a matter of interpersonal conflicts over prestige where the actual value or inner properties of objects are nearly anecdotal, everyone conforms his attitude to the independent claims of the other, and the situation degenerates into a growing state of violent reciprocity. However, in the end, there will always be a master and a slave. For the former, his victory is at the same time a defeat: the submitted person is reduced to the rank of an object and cannot therefore mirror that essential difference regarding natural life; "The Master has fought and risked his life for a recognition without value for him. For he can be satisfied only by recognition from one whom he recognizes as worthy of recognizing him." (IRH, 19). The slave, on the contrary, who was confronted with the nothingness of death, leaves the imprint of his "negatingnegativity" on the natural world. To put it differently, the slave put his nothingness to work to humanize nature. The meaning of human history is already traced. After numerous subsequent struggles, men will finally recognize themselves as identical in the reality that they constituted through the negation of the given (IRH, 45).

\section{Bataille's reinterpretation of the master and slave dialectic}

One of Kojève's students, George Bataille, understood that this novel interpretation of Hegel's Phenomenology of Spirit leaves us with a significant issue. From Hegel's monist perspective, it was possible, as we saw, to rule out the "abstract negativity" of death based on sound logical considerations. However, the exclusion of "abstract negativity" is far more problematic from the perspective of Kojève's ontological dualism. For if man truly diverges from the animal because his "I" should be defined as a "negating negativity", then we need to understand how this ontological difference could be grounded. Now, in the truest sense of the definition, only Hegel's "abstract negativity" can be considered genuine. Only death or dilapidation are, properly speaking, the true neutralization of the given. Negativity, as Hegel portrays it most of the time, is more a way to speak, or even, a mise en scène. If we take a closer look, we see that the negativity of The Phenomenology of Spirit is only a negativity in inverted commas. Why is this so? The power of nihilation, argues Bataille, can only be accepted in its most restricted sense, that is when it is subjected to the production of meaning and value. This can be seen in the case of the Hegelian slave who not only achieves a higher stage of self-reflection by maintaining himself alive in the experience of his imminent death, but also puts his "negating negativity" at work in manufacturing consumption objects for the Master. Hence, the Hegelian dialectic can be perceived as a theater play where authentic negativity is put aside. As Bataille puts it:

The privileged manifestation of Negativity is death, but death, in fact, reveals nothing. In theory, it is his natural, animal being whose death reveals Man to himself, but the revelation never takes place. For when the animal being supporting him dies, the human being himself ceases to be. In order for Man 
to reveal himself ultimately to himself, he would have to die, but he would have to do it while living - watching himself ceasing to be. In other words, death itself would have to become (self-)consciousness at the very moment that it annihilates the conscious being. In a sense, this is what takes place (what at least is on the point of taking place, or which takes place in a fugitive, ungraspable manner) by means of a subterfuge. In the sacrifice, the sacrificer identifies himself with the animal that is struck down dead. And so he dies in seeing himself die, and even, in a certain way, by his own will, one in spirit with the sacrificial weapon. But it is a comedy! At least it would be a comedy if some other method existed which could reveal to the living the invasion of death (...). ${ }^{28}$

Note here that Kojève's ontological dualism is already revised and deconstructed. The problem, Bataille contends, is that since man is immersed in the realm of meaning and value production, he fails to grasp the radical negativity of his "animal being". Usually, men do not recognize each other in their animal identity. They are separated by the nearly constant gap of rationality and work. In Bataille's own words, men live in the realm of "discontinuity". This is, at least, the basic trait of the world of the profane. Only by entering the domain of the sacred, do men transgress their most common prohibitions and somehow achieve the experience of their true "continuity" 29 as animal beings. For Bataille, the sacred is equated with the pure negativity of man as a living being. By that, he means not only, as remarked in the quote above, the death of the sacrificed victim, but also any kind of non-productive, non-goal directed practice pushing men into states of confusion and excess (e.g. the ecstatic squandering of belongings in ancient festivals). It is the most excessive and archaic dimension of human desire that Bataille's writings aim to unveil.

The title of Jacques Derrida's famous essay on Georges Bataille - "From restricted to general economy: A Hegelianism without reserve ${ }^{30 "-c a p t u r e s ~ t h e ~ s t a k e s ~ o f ~ t h i s ~ i n t e l l e c t u a l ~}$ and literary enterprise in a nutshell. The "restricted economy", is the one of value and meaning. The "general economy", on the contrary, considers the animal part-full of excess, "devoid of purpose, distinction, or meaning 31 " of man (considers, in other words, what Bataille calls The Accursed Share). This equates the idea of "A Hegelianism without reserve", that is a Hegelianism that is facing the authentic nature of the negative which cannot be fully integrated into the mere restricted economy, that is the accumulation of meaning and wealth. But Derrida's merit is also to have stressed the inherent difficulties of Bataille's project. For, to put it briefly, language is always and already meaningful, representational and purposive. Language, in other words, is always and already on the side of Hegel's dialectic, that is it is always producing new forms of meaning through logical contradictions. Regarding Bataille's attempt to capture the true nature of the sacred or of the negative, language is the most serious and inescapable obstacle ${ }^{32}$. And it is here that

\footnotetext{
${ }^{28}$ Georges Bataille, "Hegel, Death and Sacrifice", Yale French Studies 78 (1990): 19.

${ }^{29}$ For a brief introduction regarding the notions of "discontinuity" and "continuity" see Georges Bataille, Erotism, Death and Sensuality (San Francisco: City Light Books, 1986), 11-25.

30 Jacques Derrida, Writing and Difference (Abingdon: Routledge, 2001), 317-350.

31 Anthony D. Traylor, "Violence Has Its Reasons: Girard and Bataille", Contagion 21 (2014):133.

32 "In question then would be a negativity so negative that it could not even be called such any longer. Negativity has always been determined by dialectics-that is to say, by metaphysics-as work in the service of the constitution of meaning. To affirm negativity in silence is to gain access to a nonclassical type of dissociation between thought and language. And perhaps to a dissociation of thought and philosophy as discourse, if we are conscious of the fact that this schism cannot be enunciated, thereby
} 
Bataille's work either becomes, if one follows his supporters, an exceptional literary enterprise or, if one follows his detractors (and Girard certainly was one), a pure verbalism. Anyway, Bataille's ambition culminates in an anti-philosophy. In the end, he needs to multiply oxymorons and paradoxes, to amplify the commutability of words in order to void language of its meaning. To go beyond Hegel, one would have to say (or write) what is unspeakable. The deeply non-representable and irrational character of the negative can only be defended through figures of speech, through purely literary means.

To conclude this first part, I would like to add some general remarks. One may state that Bataille's writings should be treated as an extremely peculiar case and that they are not representative of the French post-Hegelianism which Girard observed from the other side of the ocean. My opinion is exactly opposite: in Bataille's works, we find a specific way of formulating the issue of violence in relation to Hegel which appears as a common denominator among French philosophers and intellectuals of this time. For instance, a conclusion that directly follows from Bataille is that Hegel chose to write his dialectic from the point of view of the slave, i.e. from the perspective of "the constitution" of work and "meaning 33". This aspect will also be pivotal for Gilles Deleuze's Nietzschean critique of Hegel where the slave occupies the place of the man of resentment ${ }^{34}$. But, more generally, authors like Klossowski, Blanchot, Foucault (at least in Madness and Civilization), Lacan, and Deleuze had, just like Bataille, a shared interest in the writings of the Marquis de Sade whose violence and excesses seemed to refer to the most unthought and obscure part of the Hegelian system, namely pure negativity. In his comments on Girard and French modern philosophy, Vanheeswijck overlooks this dimension of post-Hegelianism. This unfortunately leads him to introduce the philosophical theme of difference in a rather consensual way as merely a critique of the inherent violence of the identity principle. In fact, Descombes perfectly summarized the philosophical stake of the theme of "Difference":

Hegel had said that difference is contradictory in itself. But the question now is to pave the way for a non-contradictory, non-dialectical consideration of difference, which would not envisage it as the simple contrary of identity, nor be obliged to see itself as ' dialectically' identical with identity. 35

Hence, the pure negativity of squandering, violence, and death takes an important part in the French philosophical quest for "difference". To get rid of Hegel will amount to showing that his philosophy of identity does not capture the most brutal and excessive aspects of human existence. Yet, even if Girard agrees that Hegel underestimated the issues of human violence, he completely rejects the philosophical privilege that his contemporaries granted to the theme of "Difference". For him, just as for Hegel, "difference is contradictory in itself". Therefore, there can be no question of following Bataille's intellectual and literary project. In his critique of Hegelianism, Girard operates a radical reversal of the common issues and concerns of French modern philosophy. He asserts that Hegel's dialectic overlooks the ultimate consequences of the logical deconstruction of differences. This amounts to saying that, for several decades, French anti-Hegelianism had sought solutions by opting for the wrong direction, namely pure negativity or difference. As it has already been said, Girard was an anti-Hegelian like no other.

erasing itself, except within philosophy." - Jacques Derrida, Writing and Difference, 391. See also Ibid., 344-360.

33 Ibid., 348.

${ }^{34}$ Gilles Deleuze, Nietzsche and Philosophy (New York: Columbia University Press, 1983), 8-10.

35 Vincent Descombes, Modern French Philosophy, 136. 


\section{René Girard's deconstruction of the "struggle for recognition"}

I will now introduce, point by point, the key features of Girard's critique of the master-slave dialectic. Although the most limpid and comprehensive formulation of this critique can be found in Battling to the End, we should note that in his last essay, Girard synthesized previous works to make his final critique. In a way, it can be said that, as early as in the 1960s, Girard had already put decisive arguments in his debate with Hegel. Therefore, it is not as if he had seized the Hegelian issue at the very end of his career. Rather, it should be said that he progressively developed a comprehensive and coherent standpoint on this matter.

\section{A. Identity and difference in Girard and Hegel}

First, let us point out some important commonalities between Hegel and Girard. For both of them, as already mentioned, violence and desire are interpersonal matters. Neither Hegel, nor Girard seem to believe that violence is reducible to a simple aggressive instinct. Violence and reciprocity appear to be strongly related. As shown in our short commentary on Section B of The Phenomenology of Spirit (I.A.), agents enter into conflict because of the mutually-reinforcing nature of their claims of independency. In the blink of an eye, we move from love to a struggle to death. The "reversal of positive imitation into rival imitation" ("le retournement de l'imitation positive en imitation de rivalité. 36 ") is also a pivotal aspect in Girard's conception of human conflicts. This idea is clearly stated in texts with revealing titles such as "Friendship turning into hatred" or "Violence and Reciprocity" (V\&R, 25-29). In friendship, for instance, two persons take each other as models. They value the same kind of thoughts, artistic tastes, and sense of humor based on the other's approbation. One of them falls in love with a woman. The absence of enthusiasm or approbation from the other friend would be insulting; it would literally be a betrayal. Yet, approbation would mean a betrayal as well. For then the two friends desire the same woman and their relationship will soon enter a new stage of envy and rivalry ${ }^{37}$. Thus, both in Hegel and in Girard, we can find the pivotal ideas of good and bad reciprocity-the former always risking switching into the latter.

Although the status of "difference" with respect to identity in Hegel's logic is still a topic of sophisticated philosophical debates, what matters for our purpose is to stress the specific articulation of "identity" and "difference" in human conflicts. From this point of view, it is difficult not to agree with Marquet's statement:

But in fact, difference ... is, for Hegel, a fundamentally equivocal concept. This equivoque especially appears on a human level where one speaks of difference, of the right for difference, by considering that difference is precisely our identity or what I am. To claim for the right of difference is precisely the same thing as claiming one's identity, the right to be oneself. But this identity is an identity always and already relative to the other; it is always with respect to the other that one feels or states himself different. There is in every identity assertion an $I$ am which is the reverse side of an $I$ am not or of an I do not want to be (like you); there is always a reference to the other in the proclamation of one's identity. ${ }^{38}$

The fact that agents turn out to be identical in their claims of being different is, indeed, a pertinent feature in Hegel's thoughts on human conflicts. It is the difference proclaimed by

\footnotetext{
36 René Girard. "L'amitié qui se transforme en haine”, 199.

${ }^{37}$ Ibid., 199.

38 Jean-François Marquet, Leçons sur la Phénoménologie de l'esprit de Hegel, 60-61.
} 
each agent that stirs up the reciprocal violence of the struggle for recognition. In their attempts to be different, the rivals are too blind to see their sameness. Now, Girard certainly sympathized with this specific aspect of Hegel's philosophy. According to him, as Paul Dumouchel puts it: "The reason people keep fighting is because they do not manage to see that they are the same. ${ }^{39 "}$

Moving forward, we must ask: what is the specific meaning of "difference" in Girard's writings? Aided by this question, we enter the heart of our subject matter. Although we should not limit ourselves or be confused by this single aspect, there is, a positive characteristic of difference in Girard's writings. The first approach consists of defining "difference" in terms of the spatial and temporal distance separating human beings in their interactions and transactions ( $V \& R, 32-33)$. This distance prevents the emergence of violence insofar as: (1) it enables to delay or defer the reciprocity of human desires resulting from blind and instinctual mimicry (reciprocity is likely to backslide into the bad reciprocity of conflict); (2) it limits the situations in which mimetic desires are converging on the same objects, it limits, in other words, the risk of rivalries of appropriation. In brief, this first definition of difference encompasses the prohibitions, hierarchies, distinctions of roles and, more generally, every subdivision preventing the contagion of violence and rivalry through the whole community. However, Girard does not forget to mention that this first form of difference is, despite its undisputed functional value, mainly illusory. Ultimately, our accommodations of spatial and temporal distances in our social life are unacknowledged strategies and detours exemplifying our tendency to avoid, to a large extent, the reality of identity and sameness. As Girard puts it: "We strive, in short, to forget sameness, identity, and literally to lose it, to mislay it in the meanders of such complex differences, of such prolonged deferments that we will no longer find ourselves." (V\&R, 33). A few lines further on he adds that the "Idea of difference is not self-sufficient" and that "The current absolutism of difference is an absurdity..." $(V \nLeftarrow R, 33)$. If we consider differences as selfsufficient, or non-contradictory, then our task would be to describe the multiple cultures and societies of our world by properly accounting for their singularities. This is the standpoint of cultural and social relativism which, Girard contends, ironically excludes what is the least relative feature of mankind, namely violence. It is precisely because of the constant threat of contagious and mimetic violence that our differences exist. What is primary and real is the constant risk of the vanishing of our differences; differences which protect us from our own violence. In other words, what is real is the menace of undifferentiation (indifférenciation): "It is not difference which dominates everything, it is its effacement by mimetic reciprocity which is truly universal and which opposes the illusory relativism of the everlasting difference." ( $V \ll R, 34)$. From the very start, our cultural and social differences are the byproducts of a blind and collective scapegoating mechanism. Differences are founded in arbitrary ways, based on the resolution of a state of collective disorder where, eventually, the agents misrecognize their sameness or identity into which their own violence plunged them. We shall therefore follow Dumouchel's remarks on the notion of "illusory differences" in Girard's writings. As he puts it, "Why are these differences illusory? Because they flow from the illusion of difference and are rooted in the arbitrary nature of the [scapegoat] mechanism. It is because they legitimize the arbitrary and establish among people differences that do not exist. ${ }^{40}$ "

However, we must now ask: what is the specific meaning of undifferentiation in Girard's works? By this, Girard means that the differences separating or distinguishing the

\footnotetext{
39 Paul Dumouchel, The Ambivalence of Scarcity and Other Essays (East Lansing: Michigan State University Press, 2014), 172.

40 Ibid., 173. Italics added.
} 
agents are abolished at the climax of the mimetic crisis. However, this first characterization rests on a rather partial and limited account. One should not forget that it is the inherent dynamic of mimetic desire that lies at the core of human conflicts. An impartial person observing the struggle from the outside might conclude that the symmetry between the antagonists is growing; they are becoming more and more identical. But, the same cannot be said from the viewpoint of the antagonists themselves. Here we should not confuse mimetic desire with the desire for similarity. On the contrary, Girard keeps reminding us that what we desire appears different to us. We covet the self-sufficiency that we perceive in the model-obstacle of our desire. "It is the difference between the other and me, which my desire seeks to acquire. ${ }^{41}$ " Although all these differences are nothing more than a mirage, they nonetheless fuel the flames of conflict. This is the second meaning of difference in Girard's writings, which Dumouchel proposes to call the "illusion of difference ${ }^{42}$ ", sustaining the antagonism. If, from an external or ideal observer point of view, the similarities and symmetries of the adversaries continue to grow, then for them, the conflict is still focused on the illusion of difference. Mimesis, as Girard understands it, is pre-verbal and prerepresentational. Thus, the mimicry encouraged through rivalry is always beyond people's awareness. As stated in Violence and the Sacred: "From within the system, only differences are perceived; from without, the antagonists all seem alike. From inside, sameness is not visible; from outside, differences cannot be seen." (V\&S, 159). Put another way, undifferentiation is inseparable from the illusion of difference. If identity and mimicry are at the core of the violence effacing all social and cultural differences (illusory differences) behind it, it should not be forgotten that this dynamic rests on the agents' inability to face their sameness or identity. The dynamic rests on the illusion of difference $e^{43}$. In the most extreme forms of violence, it is always the ignorance of the real identity of the agents which is at stake. This is an unavoidable aspect in Girard's anthropology. In Violence and the Sacred, one can see that, even if almost nothing separates the antagonists, they nonetheless fail to perceive their radical sameness. Instead of recognizing their perfect similarity, the antagonists are still differentiated in their common hallucinatory state as monstrous doubles. Thereby, Girard's theory of the doubling of the mimetic rivals shows to what extent the illusion of difference is an inescapable element in human conflicts.

With the "struggle for recognition", Hegel introduced the idea of a reciprocal violence, sustained by the antagonists' persistent blindness regarding their sameness. Notwithstanding, Girard argues that the German philosopher only briefly sketched this dynamic of human conflicts. Hegel, he contends, could not have followed an intuition that would have undermined the conceptual approach of The Phenomenology of Spirit...

\section{B. Desires and Ideas: on the Hegelian categorical mistake}

Girard's anti-Hegelianism in Deceit, Desire and the Novel was probably perceived as unconvincing by his contemporaries for two reasons. First, even if Girard was already skeptical regarding Hegelian optimism (i.e. the critique of the "end of history"), and even if he aimed to show that The Phenomenology of Spirit failed to measure the extent of Western romantic illusions, he did not yet have the specific conceptual tools to attack Hegel's conception of violence and human conflicts at its core. It is only a few years later, after

\footnotetext{
${ }^{41}$ Ibid., 172.

42 Ibid., 172. Italics added.

43 "Girard says that violence is undifferentiation, but this loss of differences results from the antagonists' very efforts to distinguish themselves from each other. (...) we obtain as the pure paradoxical form of violence that violence is the assertion of a relation of identity-namely, that of doubles—through its negation, the assertion of their difference" Ibid., 175.
} 
introducing his famous ideas on "symmetry", "dissymmetry", "undifferentiation" and "monstrous doubles", that Girard was able to formulate a direct and sharp critique of the logic leading from the struggle for recognition to the master-slave dialectic. The second reason for the alleged affinity between Girard and Hegel rests on a matter of terminology. In Deceit, Desire and the Novel, the romantic heroes are entrapped in a "novelistic dialectic" where the "master" and "slave" positions permanently tend to oscillate. This question of linguistic choices, which Girard later mentions in passing in Theatre of Envy ${ }^{44}$, is perhaps not as anecdotal as it first seems. The Hegelian vocabulary of "master" and "slave" is relevant if one aims to show how relations of domination and servitude can be interpreted in terms of a mutual dependency where the submitted person holds much more power than it may first appear. This is the conclusion that can be drawn from Hegel: behind the slave's devotion for his master lies the strength which is vital for the latter. In brief, Hegel enables us to conceptualize the intrinsic reversal of roles and power relations. And this aspect, as Girard himself admits, bears some resemblances with the human relationships that lie in the romantic realm of what can only be referred to as internal mediation ${ }^{45}$. However, the notions of "master" and "slave" also maintain the idea of a differentiation or asymmetry of roles which, as one can easily see, is already not compatible with Girard's remarks on "double mediation", in which two agents, or more, become the model-obstacle for each other. As Girard puts it, "Double mediation is a melting-pot in which differences among classes and individuals gradually dissolve. It functions all the more efficiently because it does not even appear to affect diversity." (DDN, 122). The idea of undifferentiation is already there in essence. It is by pushing his reasoning further, that Girard will come to a clearer position against Hegel.

In his third book, Violence and the Sacred, Girard briefly criticizes Hegel in the chapter "From Mimetic Desire to the Monstrous Double". Here, the master-slave differentiation is the direct target of Girard's criticism:

The transferal of kudos is not simply a subjective matter, though it is not objective either. It involves a relationship in which the roles of dominating and dominated are constantly reversed. Neither psychological nor sociological interpretations can help us here. There is no point in invoking a master-slave dialectic because the situation affords no stability of any sort, no synthetic resolution. ( $V \ll S, 153-154)$

It is in this spirit that the chapter permits the reader to add more clarity to Girard's statement. In the case of the monstrous doubles, as we saw, the rivalry pushes the antagonists' ignorance of their sameness to its most extreme and hallucinatory limit. The master and slave dialectic rests on a too important dissymmetry, for it fails to show that even if nothing separates the adversaries, the illusion of difference is still at play. The conflict cannot be solved in a dialectical way because there is no sign or value of reconciliation in the agents' increasing similarity. Hence, instead of following the initial dynamic of the struggle for recognition, Hegel reconstructs this problematic relationship in the differentiated realm of "Lordship and Bondage". In other words, The Phenomenology of Spirit moves from a non-dialectical relation to a dialectical one.

\footnotetext{
44 "Mensonge romantique et vérité romanesque recourt à ce langage d'ailleurs parfaitement acceptable dans le registre des métaphores, mais qui donne une fausse couleur d'hégélianisme à une pensée en réalité pas hégélienne du tout." René Girard, Shakespeare : Les feux de l'envie (Paris:Grasset \& Fasquelle, 1990), 68. 45 "This dialectic of 'master and slave' presents curious analogies with the Hegelian dialectic, but there are also great differences." (DDN, 110)
} 
Thus, as Girard will later observe in Battling to the End, the "seeds of mimetic theory" and, by extension, the seeds that critique Hegel's philosophy were already "contained" in the idea of "double mediation" (BE, 31; $A C, 74)$, which was introduced in Deceit, Desire and the Novel. What needed to be demonstrated more clearly was the intrinsic process of human conflict, all the way to its most extreme stage, and its incompatibility with Hegel's reasoning. After Violence and the Sacred, Girard emphasized more explicitly the discordance between the Hegelian struggle for recognition and his theory of the monstrous doubles. For instance, he stated this crucial distinction in his discussion of the hallucinatory states in which the rival lovers of William Shakespeare's A Midsummer Night's Dream are entrapped ${ }^{46}$. In his last book, he puts it very concisely: "The fight to the death is thus much more than a simple desire for recognition. It is not a master-slave dialectic, but a merciless battle between twins." (BE, 41; $A C$, 89-90).

However, we shall now see how Girard formulated, in a rather concise way, the key element of his critique of Hegel prior to Violence and the Sacred, namely in his 1968 paper "Symmetry and Dissymmetry in the Myth of Oedipus". If one follows Girard's inquiry of what is happening in The Phenomenology of Spirit, Hegel argues Girard, is grounding his dialectic on a categorical mistake where the properties of ideas are wrongly attributed to human desires. To explain, at the level of concepts, identity and difference respectively correspond to the noncontradiction, and to the contradiction of ideas, but the same cannot be said for human desires, for the identity of desires is inseparable from the contradiction between the agents. As Girard put it in 1965: "The logic of desire must be distinguished from the logic of ideas. Two contradictory ideas are always, of course, two different ideas. By contrast, for two desires to oppose and to contradict one another, they must be identical. ${ }^{47}$ " The increased symmetry between the adversaries goes hand in hand with the increased will to acquire the difference separating each other. Thus, we cannot untie the relation between the identity of the agents and the illusion of difference like a dialectical or conceptual approach would require us to do. Because now, under the guise of a rigorous logic, it is exactly this irreducible relation which Hegel pretends to undo. In The Phenomenology of Spirit, the uncompromising logic of desire, which shows us that the paroxysm of identity equates to the paroxysm of contradiction, is only sketched at the very beginning of the struggle for recognition and immediately reconducted to (or reduced into) the asymmetrical domination and servitude relation where human desires can, eventually, be analyzed as concepts or ideas. For this is, in the end, precisely what Hegel aims to show us: that behind the seemingly contradictory separation of the master and the slave, we can find the opportunity for a conceptual reconciliation in the identity of two desires for recognition, a potential identity whose requirements will be met by modern institutions. Hence, Girard's critique of Hegel's categorical mistake stands perfectly in line with what he will state in later writings. In Battling to the End, Girard affirms: "Hegelian dialectic does not work for me: I find it too rationalist and not tragic enough. It flies through conflict without ruffling its feathers." (BE, 64; $A C$, 126). However, one should not forget that he already explained this point of disagreement decades earlier:

It is always the expulsion of the scapegoat, in one form or another, which resolves, in the Western world, the conflict between Same and Same. But the operation is often disguised under some flattering name: dépassement, synthesis, progress, science, humanism, religion, etc. Hegel's greatness lies in having read in history the ineluctable dilemma of Oedipus and Creon: kill or

\footnotetext{
${ }^{46}$ René Girard, Shakespeare : Les feux de l'envie, 70.

${ }^{47}$ René Girard, Oedipus Unbound: Selected Writings on Rivalyy and Desire, ed. Mark R. Anspach (Palo Alto: Stanford University Press, 2004), 28.
} 
be killed, expel or be expelled. But this dilemma was then conjured away by Hegel. He thought that two desires must behave like two concepts that cannot fail to agree once nothing separates them any longer. But in the realm of desire, this nothing is everything, since two perfectly identical desires are two desires for the same object: they pose an obstacle for each other. They are, for each other, an irreconcilable scandal. 48

This critique will eventually help us be more precise regarding the theme of identity in Girard's writings. In his ongoing opposition to the trends of French structuralism and postmodernism, Girard frequently criticized the contemporary privileges granted to "difference". In Battling to the End, he even affirms: "I will always bet on identity against difference." (BE, 71; $A C, 137)$. From a typical postmodern perspective, this statement would appear as Hegelian (i.e. from this angle, Girard would have overlooked the major philosophical stake of a non-dialectic difference). However, things are not that simple. On the one hand, Girard agrees with the Hegelian idea of self-contradictory differences. On the other hand, he argues that the Hegelian dialectic rests on an overly conceptual understanding of identity. In a radical way, Girard reverses the common perspectives of French post-Hegelianism: it is not "difference", but men's concrete sameness or identity which badly suits the exercise of dialectical thought. Hence his very original rephrasing of the issues of violence and of the necessary reconciliation of men.

\section{Hegel among the ethologists}

For Girard, Hegel's categorical mistake turns out to be an anthropological misconception. Even if he bears consideration on the Hegelian dialectic, Girard argues that the "interdividual" and reciprocal aspects of human violence are neglected too much. Far too optimistic, the Hegelian perspective on violence eventually slides back into a description which bears more resemblance to traits found in the animal kingdom than to humans per se. The slave's fear of death is a sufficient signal to stop the master's lust to kill. If we read the master-slave dialectic with a more modern eye, we could say that it bears strong resemblance to Konrad Lorenz's descriptions of the intraspecific and adaptive function of aggression with respect to some animals in the wild. In Lorenz's ethological accounts, indeed, the will to attack is also interrupted by the opponent's first signs of distress. Hegel's dialectic is, so to speak, regulated by a "violence inhibition mechanism" which makes it look suspicious for Girard:

In every duel, one has to be afraid of the other, recognize the other as master and gain recognition as the slave of that master. (...) In this sense, the master-slave dialectic has always seemed to me to be conciliatory. It resembles what ethologists tell us about dominance hierarchies in animal societies. (BE, 32; $A C, 74-75)$

If one reads, as Kojève invites us to do, the struggle for recognition as the great transition from animality to mankind, then one could contend that Girard would say that desire, violence, and reciprocity played a crucial role in the transition. But, he can only disagree with the details of this scenario, for it is the more developed biological characteristic of mimicry that sets the distance between man and animal. We then understand that the importance of human mimesis is precisely what makes violence irreducible to the master-slave dominance patterns. For Girard, there are certainly valuable

${ }^{48}$ Ibid., 86. 
intuitions in the Hegelian conception of the specificity of mankind, but, these intuitions are not arranged in the relevant way. By confusing the realm of ideas with the realm of desires, Hegel did not perceive the potential dynamic of undifferentiation implied by the struggle for recognition. He could not, thereby, see that the antagonists, turned into monstrous doubles, only escape their collective "atmosphere of terror and hallucination" (V\&S, 161) through a violent substitution mechanism in which the absolute commutability of all desires becomes polarized by the arbitrary difference of a single victim. In other words, the Hegelian desire for recognition forecloses the access to the scapegoat hypothesis. Hegel overlooked the violent origins of culture and the religious origins of mankind ${ }^{49}$. Concerning these specific aspects, Girard formulated a clear standpoint in 1976 during his correspondence with Raymund Schwager:

I believe that, scientifically speaking, we have to acknowledge that human mimetic rivalry becomes so intense that the "dominance patterns" of the animal kingdom, which represent a compromise solution [résultant d'un compromis], are no longer possible. Hence, the crisis and transition to symbolic forms of culture begins with the surrogate victim, which I conceive as the origin of symbolicity and the source of hominization. So it is possible that murder and human intelligence can be linked, but not as described by Hegel..$^{50}$

\section{René Girard's post-Hegelianism in the context of French modern philosophy}

I shall address now the question of Girard's unique standpoint with respect to the more general context of French Hegelianism and post-Hegelianism. While the confrontation of Girard's approach with that of Kojève will help add precision concerning the more notable features of mimetic desire, the confrontation with Bataille will give us the occasion to discuss Girard's standpoint with respect to the issues of the Hegelian negative and the "closure of representation".

\section{A. Bypassing Kojève's legacy}

In Battling to the End, Girard acknowledges that Kojève's work had had influence on his early writings, as in the following lines, in which one can see that he was aware of the status of Hegelianism in French modern philosophy:

Kojève's influence was huge in France. His classes at the École pratique des hautes études were attended by Raymond Aron, Georges Bataille and Jacques Lacan, and much was made of the theme of desire in Hegel's The Phenomenology of Spirit. What everyone was familiar with in Kojève's work was the notion of the master-slave dialectic, through which Hegel conceptualized the desire for recognition. At the time, everyone was talking about the "selfconsciousness" that only comes about through "consciousness of the other." A slave had to recognize his or her master. There was thus something true in the idea that the dialectic influenced my reading of novels, and what I call "novelistic truth." Like Hegel, I was saying that we desire things less than we desire for ourselves the desire that others have for things; I was talking about a desire for the other's desire, in a way. (BE, 30; $A C, 71-72$ )

\footnotetext{
49 "Human society does not begin with the fear of the "slave" for the "master," as Hegel claims, butas Durkheim maintains—with religion.” (V\&S, 306-307).

${ }^{50}$ René Girard and Raymund Schwager, Correspondence 1974-1991 (London: Bloomsbury, 2016), 28.
} 
If one wants to understand why Girard has so frequently been compared with Kojève, it is necessary to consider the following excerpt from the Introduction to the Reading of Hegel:

Desire directed toward a natural object is human only to the extent that it is "mediated" by the Desire of another directed toward the same object: it is human to desire what others desire, because they desire it. Thus, an object perfectly useless from the biological point of view (such as a medal, or the enemy's flag) can be desired because it is the object of other desires. Such a Desire can only be a human Desire, and human reality, as distinguished from animal reality, is created only by action that satisfies such Desires: human history is the history of desired Desires. $(I R H, 6)$

The resemblance with Girard's views on desire is particularly striking here. Kojève, indeed, dismissed the classical conception of desire taken as a straight line directly connecting a subject to an object. Desire is directed at objects through the mediation of another desire. There is even an obvious similitude regarding Kojève and Girard's terminology. While Kojève states that desire is "mediated" ("médiatise"), Girard contends that desire imitates the desire of a model or "mediator" ("médiateur"). Thus, at first glance, it might seem that Girard's theory of triangular desire was already formulated by Kojève in the 1930s. Do we therefore have to conclude, like Mikkel Borch-Jacobsen, that Girard mainly developed a brilliant and more radical interpretation of Kojève's work? We shall address this issue now.

George Erving, in 2003, wrote a remarkable paper on the legacy of Alexandre Kojève in Girard's writings ${ }^{51}$. First, to summarize his standpoint briefly, according to Erving the continuity between Kojève and Girard rests on the following aspects: (1) both authors are rejecting the essentialist, whether idealistic or romantic, conception of the Self taken as an object of contemplation; (2) for Kojève, and later for Girard, "Desire is constitutive of human subjectivity. That is, desire defines the Self such as one is what one desires. ${ }^{52}$ "; (3) both insist on the inscription of desire in an inter-relational dynamic, instead of defining desire as a static entity; (4) fundamentally, they consider that the force of attraction of desire does not depend on objects but on other desires; (5) in Kojève, the struggle for recognition, in which everyone competes for proving their independence regarding biological life, puts the conflictual potential of human desires at stake whereas, in Girard, each of the rivals aims to acquire the alleged self-sufficiency of their model or mediator-thereby, both of them establish a strong link between desire and violence. Hence, we see that the analogies between Kojève and Girard appear significant. One could ponder if Girard extracted Kojève's pivotal intuitions from their too restrictive and optimistic Hegelian framework. Girard, however, maintains that his "interpretation" of Kojève's work was "different from everyone else's." (BE, 30, $A C, 72)$. And he adds that he cannot precisely explain "how Hegel influenced the way" he "formulated" his "thoughts" (BE, 30, $A C, 72)$. In this statement, the status of Hegel's and Kojève's legacy seems to remain quite the enigma.

Let us now see which elements of a response can be found in Erving's study, which it should be mentioned is primarily an analysis of Deceit, Desire and the Novel. For Kojève, the fulfillment of reciprocal recognition is also the triumph of the humanization of nothingness or, put differently, of the self-production through negative activity of a proper and exclusive human reality. Thus, from Girard's perspective, the master and slave dialectic that is introducing the potential and conceptual dynamic of reciprocal recognition, already establishes an arbitrary limit concerning the extent of modern romantic illusions, this limit

\footnotetext{
${ }^{51}$ George Erving, "René Girard and the Legacy of Alexandre Kojève”,111-125.

52 Ibid., 116.
} 
being nothing but that of the "end of history" (taking place now or foreseeable for a near future). This optimism, argues Girard, fails to give us the full measure of romantic deceit. In the modern world of "internal mediation", even when people begin to face the reality of the inconsistency of their being and of the inauthenticity of their own desires, they nonetheless believe that other persons might possess the qualities they lack. It then turns out to become a game of dupes in which everyone aims to conceal his own feelings of incompleteness, to feign his indifference regarding the other (or the mediator) in order to get closer to, or acquire, his alleged self-sufficiency. In this game of illusions, the smallest sign of weakness or dependency will risk breaking the attraction of the desire of the other (who is also looking for the mediator's alleged self-sufficiency). Lordship and Bondage reach a degree of abstraction that the Hegelian dialectic was unable to suspect. For the balance of power between human beings becomes regulated by increasingly inessential qualities, such as metaphysical objects and anecdotal details. Girard therefore contends that the master and slave dialectic is too restrictive. The struggle to death in its inherent brutality, fails to capture the extent of man's vanity. Violence becomes a sign of weakness in a world where everything depends on the emotional indifference that people wish to convey:

The Hegelian dialectic rested on physical courage. Whoever has no fear will be the master, whoever is afraid will be the slave. The novelistic dialectic rests on hypocrisy. Violence, far from serving the interests of whoever exerts it, reveals the intensity of his desire; thus it is a sign of slavery. (...) In the universe of internal mediation-at least in the upper regions-force has lost its prestige. $(D D N, 112)$

If the conclusion rests on this single quote, then we may conclude that Girard radicalized Kojève by pushing his dialectic of desire beyond any reconciliatory or humanistic utopia. But the issue of Kojève's legacy is not as simple as it first seems. Girard's dismissal of reciprocal recognition actually implies important amendments regarding Kojève's theory of desire. It is at this point that we shall part company with Erving's study which lays strong emphasis on "Girard's and Kojève's overlapping ontologies ${ }^{53}$ ". Erving's inquiry is mainly focused on Girard's first essay where his ontological outlooks are the most subject to various interpretations. Now, it appears necessary to orient the study on later works to solve the Girard-Kojève issue. It is worth remembering that Kojève's theory of desire presupposes an ontological dualism where man is radically distinguished from the biological world. After Deceit, Desire and the Novel, Girard, on the contrary, progressively evolved towards a more monist ontology wherein desire depends on imitation taken as a biological trait of mankind. This new orientation in Girard's thought becomes clear in 1978 with Things Hidden Since the Foundation of the World, where his views on desire bear less and less resemblance to Kojève. In the context of mimetic desire, there can be no question of the existential stake of man demonstrating his independence with respect to biological life. Furthermore, Girard imagines imitation as being pre-verbal and pre-representational. Desire cannot involve the idea of recognizing myself, as in a mirror, in another human being. Kojève, as Erving observes, certainly insisted on the non-contemplative nature of desire, an aspect mentioned on the first page of the Introduction to the Reading of Hegel. However, the problem is that this conception of desire suffers from its incompatibility with the Hegelian idea of recognition-this is a significant internal tension (which did not go unnoticed by Bataille) in Kojève's work. In one regard, we have a non-contemplative conception of desire, and in the other, desire is still placed on the side of a philosophy of representation

\footnotetext{
${ }^{53}$ Ibid., 115.
} 
and subjectivity. Hence, from Girard's perspective, Kojève's views on desire are still too essentialist and static (which puts into question the commonalities number 1 and 3).

Let us now tackle a more difficult aspect. As noted by Erving, it seems that both Kojève and Girard attribute almost zero value, ontologically speaking, to objects (commonality number 4). It is the mediation of another desire that generates my desire for a specific object. Apparently, the proper object qualities do not play any role in the whole process. Yet, this "commonality" between Kojève and Girard turns out to be misleading. From the perspective of Kojève's ontological dualism, the status of objects is already considerably limited due to man's active negativity. The same cannot be said for Girard. Contrary to Bruno Latour's objection ${ }^{54}$, he does not deny the object's reality. First, Girard carefully distinguishes desire from appetite. Unlike desire, appetite does not depend on imitation ${ }^{55}$. Appetite does not necessarily presuppose a model or a mediator, but this does not preclude appetite from becoming mediatized by other desires, for example, this happens when some form of diets become fashionable on a social or cultural level. In the case of the scarcity of vital supplies, appetite will also become mediated and may trigger a lethal mimetic rivalry. Besides, one does not have to forget that Girard introduced a theory of triangular desire, that is a theory entailing the three subject-model-object polarities. In this context, the status of the object matters to the extent that the rivalry will depend on its degree of scarcity or on whether it is sharable or not, like television commercials involve a mediation of desire pointing at high-consumption products which, due to their abundance or to the easiness of their reproducibility, rarely occasion human conflicts, for example. Furthermore, the rivalry does not solely depend on the subject's and model's common proximity, but also on their respective distance regarding the object (e.g. a common passion or interest for an inaccessible movie star can be reinforced through mimetic desire and will not necessarily lead to a rivalry, but the more the movie star becomes accessible, the more the relation between the fans is susceptible to degenerate into bad reciprocity). Eventually, imitation is pre-verbal and pre-representational. This implies that mimesis does not operate a clear and immediate subject-object distinction. Subject and object are, so to speak, bound together in the imitation process.

Let us now consider the specific case of mimetic rivalry. $A$ starts to desire an object suggested by $B$. $A$ gets closer until reaching a significant proximity with respect to $B$ and the object. $A$ thereby becomes $B$ 's mediator and redirects his desire towards the object. $A$ and $B$ refuse to share the object and thus become a model-obstacle for each other. Gradually, the initial interest for the acquisition of the object vanishes. The antagonists, through their effort to demonstrate their superiority, through their effort to differentiate themselves are only intensifying the mimetic process operating beyond their awareness. $A$ and $B$ finally become monstrous doubles and, as we know, this situation cannot be solved through the reconciliatory operation of a dialectical process; only violence and murder will put an end to the conflict. This scenario gives the impression that we are moving from a triangular model to a dual situation where only the two antagonist's desires are at stake. Nonetheless, the object's shadow still falls over the conflict. To be more specific, we may say that the initial object mutates into increasingly abstract and inessential qualities which the rivals still aim to appropriate. It is, let us recall, the illusion of difference separating the agents that each one wishes to acquire. The initial object gradually turns into a metaphysical object. Hence, we move, as Girard states, from a leaning to appropriate the object to a leaning to "acquire the being" of the mediator or "model" (BE, 31; $A C, 73)$. In a first step, $A$ and $B$ are directed

\footnotetext{
${ }^{54}$ Bruno Latour, We have never been Modern (Cambridge: Harvard University Press, 1993), 45.

55 René Girard, Evolution and Conversion: Dialogues on the Origin of Culture (New York: Continuum International Publishing, 2008), 74-75.
} 
towards the object. In a second step, they more directly "want to be what the other becomes when he possesses this or that object." (BE, 31; $A C, 73)$. Hence, there is not, properly speaking, the idea of a "desire for the other's desire" in Girard's writings.

To sum up, while Kojève's theory of desire presupposes an ontological dualism where the antagonists aim to be recognized in their metaphysical dimension, Girard's views on desire entail an ontological monism where mimesis, taken as a pre-verbal and pre-reflexive tendency, forecloses the possibility for desire to be contemplated (i.e. recognized as a distinctive metaphysical quality by someone else). Kojève's desire for the other's desire completely rules out the ontological qualities of objects. Girard, on the contrary, introduces the hypothesis of a "desire according to that of another"5". In Girard's works, desires are never in a direct state of exchange or dialogue with each other. This would presuppose a certain form of communication where the agent's subjectivity and rationality are already at play, which leads us back to the Hegelian categorical mistake, that is to the confusion between concepts and desires. Whether they are concrete or metaphysical, objects are always at the center of the quarrel. In the end, there always remains a veil of illusion separating the two agents' desires. If certain aspects of Kojève's writings plausibly influenced Girard, one also has to acknowledge that the commonalities between the two theories of desire are far more superficial than it might seem. Eventually, Girard's vindication of the peculiarity of his conception of desire with respect to French Hegelianism is not question begging:

The desire for the other's desire has little to do with mimetic desire, which is a desire for what the other possesses, whether an object, an animal, a man or woman, or even a being unto itself, its essential qualities. I did not dare to defend my theory simply and effectively because at the time and under the circumstances I thought in such concrete terms that I could not help being disappointing: I was a little ashamed of being so prosaic. I did not dare to say that humans oppose one another over real objects. It is the desire to acquire, much more than the desire for recognition, that quickly degenerates into what I call metaphysical desire, whereby the subject seeks to acquire the being of his or her model. At such times, I want "to be what the other becomes when he possesses this or that object." (BE, 30-31; AC, 72-73).

\section{B. Getting rid of "the magical power of the negative"}

If someone aimed to radicalize Kojève's views on the Hegelian negativity, it certainly was Georges Bataille. According to Lacoue-Labarthe, Bataille addressed the pivotal issue that Girard never stopped avoiding:

The entire question is finally one of knowing if there can be a pure violence that is not the 'abstract negativity' of Hegel. In a certain way, and we always come back to this, Girard fails to come sufficiently to grips with Hegel—and Heidegger. This is what Bataille, for his part, never refused to do (...). For it is not enough to affirm that there is something "anterior" to representation if one is to overcome the logic of the said representation, which is, rigorously speaking, the interdiction of revelation. ${ }^{57}$

\footnotetext{
${ }^{56}$ Wolfgang Palaver, René Girard's Mimetic Theory (East Lansing: Michigan State University Press, 2013), 119.

${ }^{57}$ Philippe Lacoue-Labarthe, Typography. Mimesis, Philosophy, Politics, 118.
} 
This remark is interesting in many respects. Lacoue-Labarthe wrote this text in 1975 and it reflects the spirit of French philosophy during that period. This Zeitgeist might explain why Girard's anti-Hegelianism remained unnoticed and misunderstood by his contemporaries. Contrary to most of the French philosophers and intellectuals of his time, Girard did not take the alleged royal road to bypass Hegel, namely difference or (absolute) negativity. His critique of Hegel, too peculiar and also, in my opinion, far ahead of his time, was condemned to remain ignored in the French intellectual landscape of the 1960s-1970s. But Lacoue-Labarthe's remark is also interesting to the extent that, similar to Derrida, he takes into account the issues raised by Bataille's intellectual project. The quest for a pure negativity, as we saw (I.C.), encounters the unavoidable obstacle of language. In a certain way, Bataille's works are a variation, on the theme of violence, of Wittgenstein's famous statement: "What can be said at all can be said clearly; whereof one cannot speak, thereof one must be silent.". One can read Bataille's writings as a reflection on what Derrida called the closure of representation. Now, Lacoue-Labarthe wonders if Girard's approach, distinctive by his tremendous ambition to discover the generative scapegoat mechanism behind mythical representations, is not just question-begging with respect to this specific issue. In his interesting and recent comparative study on Girard and Bataille, Anthony D. Traylor unfortunately does not mention the Hegelian aspects of the debate which leads him to minimize the intrinsic philosophical difficulties of Bataille's standpoint ${ }^{58}$. That being said, Traylor's paper introduces a critique that is already found in Lacoue-Labarthe's text, that Bataille's conception of violence would be more radical and far less naïve than Girard's ${ }^{59}$. While in Girard's works, violence can still be understood in terms of a certain "functionalism", to the extent that the scapegoat mechanism is the structuring element of the religious and the social, Bataille would be more inclined to acknowledge the purely destructive aspects of human violence undermining any attempt of rationalization. This opposition becomes less clear if one takes into account the apocalyptic dimension of Girard's anthropology laying emphasis on the fact that the increasing loss of efficiency of sacrificial mechanisms confronts men with the inescapable threat of an increasingly global and uncontrollable state of violence. Notwithstanding, I shall now discuss the aforementioned issues by staying focused on the Hegelian aspects.

It should be noted that, in their confrontation with Hegel, Bataille and Girard are not at all interested in the same questions. As stressed by Derrida, it is the privileged position of the slave in Hegel's dialectic which constituted Bataille's pivotal matter of interrogation. Since Bataille aims to question the primacy of meaning and value production in the dialectical process, it is the "dissymmetry" between master and slave which remains his central interest ${ }^{60}$. This is somehow reminiscent of Deleuze's critique which, while maintaining the distinction of roles in Hegel's dialectic, aims to deconstruct its axiology. To state it briefly, Deleuze contends that Hegel's reasoning is biased because it is entirely written from the perspective of the slave ${ }^{61}$. In this Nietzschean critique, the slave is the man of resentment, the "reactive" person incapable of defining oneself otherwise than through opposition to another. The slave seems to ignore the existence of self-affirmation. He

\footnotetext{
58 Anthony D. Traylor, "Violence Has Its Reasons: Girard and Bataille”, 131-166.

59 "Hence the relative naiveté of the hypothesis of an original founding act that is really 'violent', and the relative naivete of the concept of violence that is here put into play." Philippe Lacoue-Labarthe, Typography. Mimesis, Philosophy, Politics, 118.

60 "It is this dissymmetry, this absolute privilege given to the slave, that Bataille did not cease to meditate. The truth of the master is in the slave; and the slave become a master remains a 'repressed' slave." Jacques Derrida, Writing and Difference, 322.

${ }^{61}$ Gilles Deleuze, Nietzsche and Philosophy, 8-10.
} 
ignores that some persons are different in a comprehensive and non-contradictory way. Only the standpoint of resentment with its hatred for genuine differences can propel the dialectical perspective on the master-slave relation where, in the end, only the identity of the two agents will remain. These questions do not interest Girard at all. Generally speaking, he understands difference as a contradictory concept. Besides, for him, the idea of selfaffirmation (or self-sufficiency) is nothing more than a romantic illusion. While Bataille and Deleuze aim to redefine the master and slave dissymmetry in a different way, Girard's concern is the issue of symmetry. According to him, Hegel failed to perceive the ultimate consequences of the logic of violent reciprocity. The Hegelian dialectic overlooked the law according to which the increasing symmetry between men triggered by the sameness of their desires is exactly proportional with their degree of violent contradiction.

A superficial reading of Girard's remarks on Hegel might give us the impression of a certain commonality with Bataille's critique. Both authors, indeed, are questioning the setting aside of excessive violence in the master-slave dialectic. In Battling to the End, Girard states:

It is obvious that, for there to be recognition, the master, who makes me exist simply by looking at me, must not be killed! Human consciousness is not acquired through reason, but through desire. Adversaries thus enter into conflict in order to gain recognition. The desire for recognition prevents them from killing each other. How would they be able to recognize each other if one of them died or they were both killed? (BE, 31-32; $A C, 74)$.

Here, Girard directly questions the contemplative dimension of Hegel's dialectic of desire. Violent death is prevented through the idea that desires might enter into a conscious state where each one could see his reflection in the other. But the problem is that, according to Girard, this mirror game goes beyond the agent's awareness; it goes beyond their illusion of difference and produces a lethal symmetry. We cannot introduce a logic of intersubjective communication in the conflictual dynamic of human desires. Bataille's thoughts, on the contrary, entirely depend on this contemplative aspect of Hegel's dialectic. Bataille aims to see what cannot be seen. The issue of vision remains crucial in his work. Let us remember what he wrote:

For when the animal being supporting him dies, the human being himself ceases to be. In order for Man to reveal himself ultimately to himself, he would have to die, but he would have to do it while living-watching himself ceasing to be. ${ }^{62}$

This whole reasoning is part of Kojève's legacy. For Kojève tried to combine two different and incompatible aspects, namely a philosophy of representation and subjectivity with the non-representational notion of "negating negativity". One then necessarily remains entrapped by an unsolvable problem. Bataille claims that one cannot contemplate what is not representable: the negative. He thus pushed the internal contradiction of Kojève's philosophy to its most extreme limit. Girard, on the contrary, found a coherent way to bypass this contradiction: mimetic theory. While Bataille keeps asking questions on Hegel's "abstract negativity" (i.e. death), Girard directly criticizes the representational and subjective aspects of the master-slave dialectic which put aside the issue of the human lust to kill. While the former wrote on the unknowable nature of death, the latter was concerned by the imperious problem of murder. Girard's irony and lack of interest in the question of the

${ }^{62}$ Georges Bataille, "Hegel, Death and Sacrifice", 19. Italics added. 
contemplation of the negative can be seen in his comments on the beheading of John the Baptist in The Scapegoat:

By espousing the violent desire of Salome, all the guests feel as if they are satisfying their own desire. Everyone shares the same frenzy toward the model obstacle, and they all willingly mistake the object because the proposed object feeds their appetite for violence. It is not Hegelian negativity or the impersonal death of the philosophers that guarantees the symbolic quality of the prophet's head, but the mimetic contagion of collective murder. ${ }^{63}$

It is Girard's contention that the philosophical concept of negativity is always betrayed by its sacrificial and violent origins. Negativity is nothing but sacralization of violence. We have to change our understanding of philosophical concepts through the study of the religious, and not the other way around. Negativity therefore remains a mystified and abstract notion in Girard's view. Hence, as we shall see in our conclusion, his criticism of the sacrificial aspects in Hegel's philosophy.

Nonetheless, it is true that the "closure of representation" is a common theme in Bataille's and Girard's writings. For Girard, the scapegoat mechanism works blindly. The generative process of religious symbols involves the ignorance of the violent crowd. Girard sometimes argued that, since the "closure of representation" instituted through myths cannot be bypassed by our common human knowledge, the Christian revelation of the scapegoat mechanism has to be divine. Other elements of response, however, can be given. First, a certain number of epistemological considerations are worth being mentioned. The hypothesis of pre-verbal and pre-representational form of mimicry, for instance, can find a field of application in experimental psychology ${ }^{64}$. Besides, Girard vindicated his theories from the perspective of their explanatory power. The idea of a generative scapegoat mechanism does not multiply entities without necessity and aims to account for myths and rituals in their diversity. Furthermore, Girard frequently employs the methodology of the consilience of inductions wherein results obtained by mutually independent inquiries converge towards the same explanation or hypothesis; this is especially notable in the case of his study concerning the Oedipus myth in which different approaches encourage the same conclusions.

Some remarks should be added which are more directly related to Girard's critique of Hegelianism. The categorical mistake argument that he states against Hegel (II. B.) is not merely an abstract one. To confuse the realm of concepts with the realm of desires is like confusing two distinct perspectives regarding human conflicts. "From within the system, only differences are perceived; from without, the antagonists all seem alike. From inside, sameness is not visible; from outside, differences cannot be seen." ( $V \ll S$, 159). Hegel mistook the external point of view for being the conceptual logic of the struggle from within. This aspect clearly demonstrates that Girard's debate with Hegel is not directly about the limits of language or representation. There is almost an empirical dimension in his objection. For Girard aims to stay at a close distance from what can actually be observed in the dynamic of conflicts. With the help of historical and spatial distance, the general loss of cultural, or illusory, differences can be observed in the context of a social crisis or, in a more theatrical form, in archaic rituals. However, from this objective phenomenon of undifferentiation one cannot legitimately infer a conceptual form of identity between human

${ }^{63}$ René Girard, The Scapegoat (Baltimore: John Hopkins University Press, 1986), 135. Italics added.

64 See for instance Andrew N. Meltzoff, "Out of the Mouths of Babes: Imitation, Gaze, and Intentions in Infant Research-the 'Like Me' Framework", in Mimetic Theory and Science, ed. Scott R. Garrels, (East Lansing: Michigan State University Press, 2011), 55-74. 
beings (like Hegel's desire for recognition invites us to do). Instead, what is needed is an explanation of the internal process through which differences are getting lost. As such, the most empirical approach will consider the external and internal perspectives on the conflict, and then establish articulation in the most relevant and plausible way. Now, this is exactly what Girard intends to do when he formulates the hypothesis that undifferentiation is sustained by the illusion of difference for which the agents are struggling.

In his recent discussion of the Hegelian desire for recognition, Dumouchel stressed the empirical difficulties of the concept regarding the study of human conflicts ${ }^{65}$. His paper shows that Paul Ricœur and Axel Honneth, who both proposed a modernization of recognition, are confronted with the same issues. Since it presupposes the conceptual identity of the adversaries, the struggle for recognition can only be considered as an effort or as a dynamic towards the realization of this potential logic. Said differently, the struggle for recognition should be considered as "morally progressive". This can be interpreted in two ways: either all forms of conflicts are morally progressive, or only some specific kinds of struggles can be described in these terms. The former case rests on a conception of human conflicts which, given the massive damages of wars, genocides, terrorist attacks, immediately appears as counter-intuitive. We could maintain the idea of recognition by constantly differing its realization in the history of human relations. But this is, as Girard contends, at the very opposite of an empirically-informed approach: the "unity" of "reality and thought" (that is, more generally, the unity of human beings) is placed at "the end of the indeterminacy of history" ( $B E, 32-33 ; A C, 76)$. A second possibility would be to distinguish genuine struggles for recognition from other types of conflicts. However, at the present time, no clear-cut criterion of demarcation has been found (it is also difficult to see how this second perspective could be distinguished from the former, since we do not really know how to define the time-span of a recognition process in objective or measurable terms). Eventually, as Dumouchel observes, actual cases of recognition, like ceremonial exchanges or peace processes between foreign States, do not necessarily appear as empirical evidence for the Hegelian conception. For instead of exemplifying the realization of a dyadic communicative action, instances of recognition rest on the existence of a third-party such as a symbolic object or past historical event, or a witness exerting his external and performative authority, which objectifies the relation by creating a new and different common reality. Put otherwise, recognition is an "artifact" or an illusory difference. Hence, an empirical application of Girard's categorical mistake argument proves to be very convincing and fruitful.

Concerning the idea that Bataille's conception of violence would be less naïve or more radical than Girard's, I will limit myself to a simple remark. It is often mistakenly believed that the mere insistence on human destructiveness is the surest sign of a pessimistic and down-to-earth attitude. But, Bataille's writings show us that things are not that simple. If one aims to bypass Hegel by struggling with the very limits of rational discourse, he also risks transforming the issue of violence into a purely literary matter. For here is the strange, and very French, paradox of this kind of anti-Hegelianism: the more one focuses on the terrible nature of violence transcending all the limits of language, the more one converts violence into a purely verbal issue. In the end, the over-insistence on the disturbing aspects of human violence hardly conceals the issue of the derealization of violence. It is to René Girard's merit to have bypassed this common post-Hegelian trap (that Bataille fell into).

\footnotetext{
${ }^{65}$ Paul Dumouchel, “Fare i conti con il riconoscimento”, Tropos VI-1 (2013): 97-107.
} 


\section{Conclusion}

"The danger in Hegel's thought", states Girard, "comes paradoxically from the fact that it does not begin with a sufficiently radical conception of violence." (BE, 32; $A C 75)$. It is worth mentioning that some of Hegel's commentators also raised the issue of the derealization of violence in his philosophy. In this respect, Gérard Lebrun ${ }^{66}$ and Vittorio Morfino wrote sharp remarks. Both were interested in the status of violence in Hegel's Science of Logic and their conclusions are very similar. For the sake of concision, I quote Morfino's comment on the status of violence [Gewalt] in Hegel's reflections on causality:

In short: 1) violence is necessary; 2) violence is not real, it is not wirklich, not only because it is not violence that acts, wirken, and produces an effect, Wirkung, i.e., it is not the motor of the process; but also because its occurrence is the effect of an optical illusion produced by the final level of the binary logic of the metaphysical categories [Wirkung und Gegenwirkung], the illusion of a duality that will be resolved in the unity of the Idea. ${ }^{67}$

On the one hand, violence is necessary because, as Tinland observes ${ }^{68}$, it occasions the emergence of oppositions and dynamics on which dialectical reasoning will be able to work. On the other hand, violence is not real because the self-sufficiency of the Hegelian Reason bypasses the contingent and inessential elements of the dialectical process. This very logic is illustrated through the struggle for recognition where the violence of the conflict permits the philosopher to start a speculative reasoning on human interactions but, at the same time, turns out to be an optical illusion with respect to the antagonist's rational and moral identity (i.e. violence is an inessential quality which does not characterize recognition in its essence). In a previous paper, I aimed to show that Hegel's philosophy rests on the permanent rejection of the foundational role of violence ${ }^{69}$. Hegel clearly stated that while the struggle for recognition can somehow be considered as the oppressive and violent origin of a common life between men, it cannot be considered as a foundational element regarding the modern legal and political order ${ }^{70}$. In world history, the violence and tyranny of "great men" ("große Menschen") are inessential and contingent for they impose on the population what will later become their rational and moral will as citizens ${ }^{71}$. Besides, when regarding the issue of international wars Hegel claims that "Weltgeschichte ist Weltgericht" " the world is the world's court of judgement") ${ }^{72}$, this does not mean that Universal Reason delivers violent sanctions. States perishing through war have already lost their "ethical health". From the perspective of Universal Reason, their death appears as a suicide. The rational principle once embodied by their Volksgeist becomes outdated and, in the end, the

66 Gérard Lebrun, L'envers de la dialectique : Hegel à la lumière de Nietzssche (Paris : Seuil, 2004).

67 Vittorio Morfino, "The Syntax of Violence: Between Hegel and Marx", Historical Materialism 17 (2009): 85.

68 Olivier Tinland, "Hegel", in Dictionnaire de la Violence, ed. Michela Marzano (Paris : Presses Universitaires de France, 2011), 614.

69 Andreas Wilmes, "Critique et déréalisation de la violence dans la philosophie de Hegel", in Figures Philosophiques du Conflit, ed. Andreas Wilmes \& Joan-Antoine Mallet, (Paris: L'Harmattan, 2015), 117157.

${ }^{70}$ Georg Wilhelm Friedrich Hegel, Enzyklopädie der philosophischen Wissenschaften, III (Frankfurt am Main: Suhrkamp Verlag, 1986), \ 433.

${ }^{71}$ Georg Wilhelm Friedrich Hegel, Vorlesungen über die Philosophie der Geschichte (Frankfurt am Main: Suhrkamp Verlag, 1989), 46.

72 Georg Wilhelm Friedrich Hegel, Grundlinien der Philosophie des Rechts (Frankfurt am Main: Suhrkamp Verlag, 1989), \ 340. 
Absolute Spirit always detaches itself from the peculiar configurations which pretended to tie its meaning once and for all.

These considerations would normally lead us to Girard's discussions on Hegel, Clausewitz and international wars. However, our conclusion is not the right place for addressing this topic. Instead, we shall acknowledge that Girard's critique of the lack of radicalism in Hegel's conception of violence makes sense on both anthropological and philosophical levels. In a nutshell, Girard's issue with Hegel is that he perceives the idea of a philosophical Reason entirely detached from violence and conflict as misleading, utopic and, eventually, dangerous. As he argued in his conversations with Benoit Chantre at The Centre Pompidou (2008): "[Hegel] overlooks what makes the essence of the archaic and what makes the essence of Christianity." ("... rate ce qui fait l'essence de l'archaïque et ce qui fait l'essence du christianisme."). In other words, the German philosopher overlooked the issue of the founding of violence and of its unveiling. This aspect is inseparable from the Hegelian idea that philosophy could occupy an external and impartial position regarding violence and human conflicts. Interestingly, Girard acknowledges that he once was deluded by this seductive utopia:

You cannot view it [history] from above or get an eagle-eye view of the events. I myself thought that was possible when I was writing Things Hidden Since the Foundation of the World, in which I imagined Christianity provided the point of view from which we could judge violence. However, there is neither non-sacrificial space, nor "true history. (BE, 35; $A C, 79-80)$

The loss of sacrificial mechanisms triggered by the Christian Revelation confronts us with a violence which, deprived of its foundational value, gets more and more out of our control. In this Apocalyptic context, there can be no question of adopting a rationalist God's eye view confident in the necessity of mankind's reconciliation. "Hegelian synthesis", argues Girard, "is a catharsis ... a very enlarged catharsis happening at a global level" (" $L a$ synthèse hégélienne est une catharsis... une catharsis très élargie et qui se produit au niveau mondial'Centre Pompidou, 2008). Girard, as I understand him, seems to say that, nowadays, the most abstract sacrificial mechanisms might also be the most dangerous. In the end, the Absolute Spirit is based on the perpetual denial of its violent foundations, as we saw, violence is at the same time necessary and not real. Ultimately for Girard, human beings are sacrificed on the altar of the rationalist illusion. Human history illustrates this incredible ability to perceive even the most destructive conflicts as a sign of reconciliation to come. In the textual mechanisms of German idealism, and in its most obscure concepts such as negativity, we find something of the murderous folly of men. "Philosophy", even at its most abstract level, "is a direct extension of the structures of the sacred. ${ }^{73}$ "

\section{References}

Bataille, Georges. "Hegel, Death and Sacrifice". Yale French Studies 78 (1990): 9-28. Erotism, Death and Sensuality. San Francisco: City Light Books, 1986.

Borch-Jacobsen, Mikkel. Lacan, le maître absolu. Paris: Flammarion, 1995. Folies à plusieurs. De l'bystérie à la dépression. Paris : Seuil, 2002.

Chantre, Benoît. Les derniers jours de René Girard. Paris : Grasset \& Fasquelle, 2016. " "René Girard in France". Contagion 23 (2016) :13-61.

Deleuze, Gilles. Nietzssche and Philosophy. New York: Columbia University Press, 1983. Derrida, Jacques. Writing and Difference. Abingdon: Routledge, 2001.

\footnotetext{
${ }^{73}$ René Girard and Raymund Schwager, Correspondence 1974-1991, 158.
} 
Descombes, Vincent. Modern French Philosophy. New York: Cambridge University Press, 1980.

Domenach, Jean-Marie. Enquête sur les idées contemporaines. Paris: Seuil, 1981.

Dubouchet, Paul. De Georg Wilhelm Friedrich Hegel à René Girard. Violence du droit, religion et science. Paris : L'Harmattan, 2015.

Dumouchel, Paul. "Fare i conti con il riconoscimento". Tropos VI-1 (2013): 97-107. The Ambivalence of Scarcity and Other Essays. East Lansing: Michigan State University Press, 2014.

Erving, George. "René Girard and the Legacy of Alexandre Kojève”. Contagion 10 (2003): 111-125.

Foucault, Michel. "The Order of Discourse" (Inaugural Lecture at the Collège de France, 2

December 1970)". In Untying the Text: a Post-Structuralist Reader, ed. Robert Young, 51-78. Boston: Routledge, 1981.

Girard, René. Deceit, Desire and the Novel. Baltimore: John Hopkins University Press, 1965. . Violence and the Sacred. Baltimore: Johns Hopkins University Press, 1977.

. Des choses cachées depuis la fondation du monde. Paris: LGF, 1983.

. The Scapegoat. Baltimore: John Hopkins University Press, 1986.

Shakespeare: Les feux de l'envie. Paris:Grasset \& Fasquelle, 1990.

Oedipus Unbound: Selected Writings on Rivalry and Desire, ed. Mark R. Anspach. Palo

Alto: Stanford University Press, 2004. . Evolution and Conversion: Dialogues on the Origin of Culture. New York: Continuum

International Publishing, 2008. . "L’amitié qui se transforme en haine". In Cabier René Girard, ed. Mark R. Anspach, 198-202. Paris: Editions de L'Herne, 2008.

. Battling to the End. East Lansing: Michigan State University Press, 2010. - Achever Clausewit: Paris: Flammarion, 2011.

. "Violence et Réciprocité". In Celui par qui le scandale arrive, 15-43. Paris :

Fayard/Pluriel, 2011.

Girard, René and Schwager, Raymund. Correspondence 1974-1991. London: Bloomsbury, 2016.

Goldmann, Lucien. “ Marx, Lukács, Girard et la sociologie du roman”. Méditations, revue des expressions contemporaines 2 (1961) :143-153.

Hegel, Georg Wilhelm Friedrich. Phänomenologie des Geistes. Frankfurt am Main: Suhrkamp Verlag, 1970. . Ensyklopädie der philosophischen Wissenschaften, III. Frankfurt am Main: Suhrkamp Verlag, 1986. . Grundlinien der Philosophie des Rechts. Frankfurt am Main: Suhrkamp Verlag, 1989. . Vorlesungen über die Philosophie der Geschichte. Frankfurt am Main: Suhrkamp Verlag, 1989.

Kojève, Alexandre. Introduction to the reading of Hegel. Ithaca: Cornell University Press, 1980.

Lacoue-Labarthe, Philippe. Typography. Mimesis, Philosophy, Politics. Palo Alto: Stanford University Press, 1998.

Latour, Bruno. We have never been Modern. Cambridge: Harvard University Press, 1993. Lebrun, Gérard. L'envers de la dialectique : Hegel à la lumière de Nietasche. Paris : Seuil, 2004. Marquet, Jean-François. Leçons sur la Phénoménologie de l'esprit de Hegel. Paris : Ellipses, 2009.

Meltzoff, Andrew. "Out of the Mouths of Babes: Imitation, Gaze, and Intentions in Infant Research—the 'Like Me' Framework”. In Mimetic Theory and Science, ed. Scott R. Garrels, 55-74. East Lansing: Michigan State University Press, 2011.

Morfino, Vittorio. "The Syntax of Violence: Between Hegel and Marx". Historical Materialism 17 (2009): 81-100. 
Palaver, Wolfgang. René Girard's Mimetic Theory. East Lansing: Michigan State University Press, 2013.

Pinkard, Terry. Hegel's Phenomenology. The Sociality of Reason. Cambridge: Cambridge University Press, 1996.

Schwager, Raymund. Must There Be Scapegoats? Violence and Redemption in the Bible. New York: Gracewing, 2000.

Tinland, Olivier. "Hegel”. In Dictionnaire de la Violence, ed. Michela Marzano, 613-617. Paris : Presses Universitaires de France, 2011.

Traylor, Anthony D. "Violence Has Its Reasons: Girard and Bataille". Contagion 21 (2014):131-156.

Vanheeswijck, Guy. “The Place of René Girard in Contemporary Philosophy”. Contagion 10 (2003): 95-110.

Webb, Eugene. The Self Between. From Freud to the New Social Psychology of France. Seattle: University of Washington Press, 1992.

Wilmes, Andreas. "Critique et déréalisation de la violence dans la philosophie de Hegel”. In Figures Philosophiques du Conflit, ed. Andreas Wilmes \& Joan-Antoine Mallet, 117-157. Paris: L'Harmattan, 2015.

\section{List of Abbreviations}

AC: Girard, René. Achever Clausewitz: Paris: Flammarion, 2011.

BE: Girard, René. Battling to the End. East Lansing: Michigan State University Press, 2010.

DDN: Girard, René. Deceit, Desire and the Novel. Baltimore: John Hopkins University Press, 1965.

PHG: Hegel, Georg Wilhelm Friedrich. Phänomenologie des Geistes. Frankfurt am Main: Suhrkamp Verlag, 1970.

IRH: Kojève, Alexandre. Introduction to the reading of Hegel. Ithaca: Cornell University Press, 1980.

V\&R: Girard, René. "Violence et Réciprocité". In Celui par qui le scandale arrive, 15-43. Paris: Fayard/Pluriel, 2011.

V\&S: Girard, René. Violence and the Sacred. Baltimore: Johns Hopkins University Press, 1977.

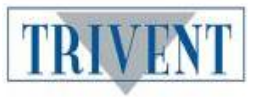

The PJCV Journal is published by Trivent Publishing. 